\title{
The Arab Spring and Its Implications for Nigerian National Security
}

\author{
Chukwuma Osakwe ${ }^{1}$ \\ ${ }^{1}$ Department of History and International Studies, Nigerian Defence Academy, Kaduna \\ Correspondence: Chukwuma Osakwe, Department of History and International Studies, Nigerian Defence \\ Academy, Kaduna. Tel: 234-807-949-5577. E-mail: lecturec@yahoo.com
}

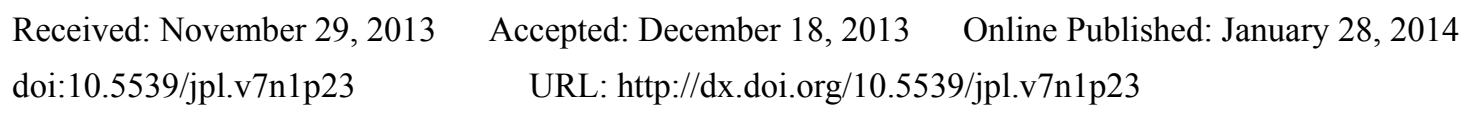

\begin{abstract}
Demographic changes, growing unemployment, social media penetration, an interplay of religion and politics provided the combustible mix for the Arab Spring. The Arab Spring has helped generate awareness about quality of governance, legitimacy and relationship between state and society but is muted as it relates to its effects on national security in Nigeria. Indeed, from a historical perspective, a direct effect of the Arab Spring on Nigerian National Security is not obvious. The paper argues that the challenges facing national security in Nigeria is independent of the Arab Spring but identifies some ripples from the Arab Spring that could create anxious moments for national security planners in Nigeria.
\end{abstract}

Keywords: Africa, Arab Spring, Arab Awakening, Middle East, national security, Nigeria

\section{Introduction}

Momentous events have a way of connecting individuals to one another and ultimately to history. What has gone down in history as the "Arab Spring" was a series of social protests, demonstrations, riots and uprisings that began in Tunisia, in January of 2011. Subsequently it spread to other North African countries such as Egypt, into the Middle East countries and has percolated to as far as Iran. The initial characteristic fervor of the so called Arab Spring may have mellowed but its agitation is continuing and in some countries it has mutated into civil war and all manner of reform and repression bordering on human rights abuses. However, for an on-going process a full assessment or a post mortem, or even its implication will be a difficult undertaking. What is clear is that an examination of the root cause is interwoven in an interplay between socio-economic factors, geo-strategic environment and the realities of both politics and religious understandings. Therefore an assessment of these factors is highly relevant to an understanding of their relationship as a whole to Nigerian National Security. If anything, it should be analyzed conveniently in the short term, the mid-term and the long term. But before engaging in any analyses it would be proper to clarify some concepts, terms and terminology.

\section{Clarifications Arab Spring: Does the Noun Fit the Event?}

As a precursor to this discussion, it is important to note that the use of "Arab Spring" to describe the momentous events that have engulfed the region is a misnomer. First, since it is still on-going from January of 2011, it stands to reason that these events have gone past more than one spring season notwithstanding other European seasons such as the Fall, Summer and Autumn. Thus, there is no consensus on what to call these seismic like movements that have engulfed North Africa, the Middle East and Persia. People in the Arab World prefer to call it the "Arab Awakening" (Rogan, 2011) while others call it names depending from which ocular perspective they are analyzing the events. For instance, "Tunisian Spring", "Tunisian Wind", "Tunisian Revolution" or the "Jasmine Revolution" (Alfano, 2011) (because of the preponderance of the Jasmine flower in Tunisia) have come to be found in some of the literature of this trend. Yet as an event or movement that is still on-going, the historian would most likely refrain from calling these events a reform or a revolution. What is certain is that as the events unfold the scholar, in order not to rush into judgment, would consider the Arab Spring to date as evolving and the entire phenomenon evolutionary. For the purposes of this paper we will use these nouns and terms interchangeably respecting the preferred nomenclature in any of the countries under consideration.

\section{Origin and Cause(s) of the "Arab Spring"}

It is not in doubt that cataclysmic events, reformist or revolutionary as it may be must have remote and immediate causes. While the remote cause(s) is outside the scope of this paper, the immediate cause(s) and course which may have implications for Nigerian National Security is difficult to account for. First, the 
movements and or uprising span a large expanse of land comprising of about twenty countries. Generalisations will not take into full consideration the cultural variations and the peculiarities of each country. This difficulty is appropriately captured by Rogan (2011) when he avers that:

There is a tendency to talk about the Arab Spring as though it were a monolithic phenomenon. It is true that many of the national uprisings have common features. The demonstrations are largely driven by younger citizens, using cell phones and social networking websites to circumvent state controls. There is no visible leadership in any of these essentially grassroots movements. They use the same slogans and tactics as Arab citizens in other countries, learning from the successes of revolutionary movements in other Arab countries.

Nevertheless, it is generally agreed that events in Tunisia from December 17, 2010 shed light on the immediate cause of what has now become the Arab Awakening. On that day, Muhammad Bouazizi, an unemployed university graduate who turned a street vendor selling vegetables to make ends meet had his wares and cart confiscated by a female police officer. Muhammed had not acquired a licence to sell goods. Prior to this incident, Muhammed had a similar experience and when he tried to pay the fine, a policewoman spat on his face, slapped him and insulted his deceased father (Alfano, 2011). Such a gender interaction in that part of the world impugns the dignity of the man. However, when he went to the provincial headquarters to complain for this incident on December 17, he was not given audience by the officials. After a couple of hours he returned to the municipal headquarters with flammable liquid and self immolated himself (Alfano, 2011). Once his action made it to the air waves it triggered Tunisians pent up anger and frustration in the form of riots and violent demonstrations. The intensity of the protests led to the stepping down by President Zine El Abidine Ben Ali from power on the $14^{\text {th }}$ of January, 2011. This populist pressure was not confined to Tunisia alone. It spread to other North African countries and into the Middle East (McKay, 2011).

\section{Review of Related Literature}

In general, literature on the Arab Spring is in its infancy but developing. There is a paucity of books but a significant number of articles and commissioned papers for a relatively new subject. Virtually none is in existence with respect to its implication for Nigerian National Security. However, a review of the commissioned papers and journal would show the obvious rush to the press in the analyses and since the so called Arab Spring is on-going. In all, however, the current state of literature is a good glean into what has happened and what is still happening in the broad spectrum of the Arab Awakening.

One of the early writings on the Arab Awakening came from Foreign Affairs of May/June of 2011. In its sub title The New Arab Revolt it posed the following questions: what just happened; why no one saw it coming; what it means; and what comes next. In trying to answer the questions Lisa Anderson (2011) tried to demystify the Arab Spring by noting that the upheavals in Tunisia, Egypt and Libya followed different paths because of their 'vastly different cultures and histories'. Anderson (2011) concludes by recommending to Washington that it 'must come to grips with these variations if it hopes to shape the outcomes constructively'.

Goldstone (2011) declares that revolutions rarely succeed except for ones against corrupt and authoritarian regimes. This he concludes would explain why Ben Ali of Tunisia and Hosni Mubarak of Egypt fell from power and why some governments in the region will prove more resilient. Doran (2011) takes the reader down memory lane to show that the uprisings of the 1950s can help the United States navigate the current crisis. Doran (2011) projects that Iran and Syria will try to manipulate 'various local grievances into a unified anti-western campaign'. Shehata (2011) concludes that the fall of Mubarak was because of his regimes corruption, alienation of her youth, the politics of exclusion and divisions among the country's elites. In sum, how those elites and the youth realign would determine if post Mubarak Egypt will emerge as a true democracy. Taleb and Blyth (2011) link the Middle East upheavals to the global financial crisis. 'When policymakers try to suppress economic or political volatility, they only increase the risk of blowups'. Hamid (2011) sees in the Arab Revolt the rise of Islamists and may lead to the first 'sustained experiment in Islamist government'. But in a consolatory tone he conjectures that 'today's mainstream Islamist groups tend to be pragmatic- and ready to compromise if necessary on ideology and foreign policy'. Finally, Byman (2011), observes that the uprisings 'damaged the jihadist brand' but it also gave terrorist groups greater operational freedom. He called on Washington to continue the pressure on al Qaeda and 'work closely with any newly installed regimes.

Similar to the positions taken by the contributors of Foreign Affairs are a collection of articles from $e$ International Relations. A few of these contributions are worth noting. Jones (2011), contend that the Arab Spring in Yemen has brought up long suppressed national, ethnic, tribal and religious identities. As a result, the very nature of state identity is contested. The state is 'less an independent political actor and more a political 
field where diverse actors compete for influence and resources'. Entessar (2011) observes that for Iran, the Arab Spring, reminiscent of the Green Movement in 2009, will present opportunities and pose challenges for Iran. Toby Jones (2011) is even more emphatic by stating that the Persian Gulf is a tinderbox with the complex interplay of politics and religion by Saudi Arabia and Iran especially with respect to Bahrain and Yemen. From the tone of the writing both countries are seen as opponents of the Arab Spring. Furthermore, O'Connell (2011) offers a panacea on how to save a revolution by declaring that: "The revolutions in Tunisia and Egypt succeeded in part because the opposition employed non-violence".

The Conservative Middle East Council (CMEC) publication is deserving of a review. In general and as it pertains to Britain, the North Atlantic Treaty Organization (NATO) intervention in Libya and the sweeping away of the status quo is a success. But the uncertainty in Syria is troubling. However, possibilities and probabilities remain in Egypt, Tunisia, the Gulf Cooperation Council (GCC) states, a viable Palestinian state and Israel, and the roles of Turkey and Iran (Docherty, 2011). But Willis (2011) was more emphatic. Using Tunisia as a trailblazer and the benchmark he avers that five discredited assumptions stand out with respect to the Arab Spring:

Firstly, that authoritarian regimes in the region were inherently stable. Secondly, that democracy and democratic aspirations were unsustainable in the Arab world because ordinary populations were culturally inclined to authoritarian rule. Thirdly, that any mass organized opposition to the ruling regimes would invariably be Islamist and undemocratic in nature. Fourthly, that the demands and interests of populations in the region were fundamentally different from those elsewhere. Finally, that any meaningful political change would have to be initiated from outside of the region by external actors.

These discredited assumptions are significant as they may have implications for elsewhere in the world such as in Nigeria. Closely tied to these assumptions is a warning by Shaikh that the tactics of the GCC nations in using 'economic payouts to stem the tide of popular discontent is likely not to be sustainable. The GCC nations spent in 2011 “a whopping \$160 billion' for such payouts, possible only because of the high oil prices. Shaikh (2011) observes that "there is increasing research evidence to show that oil wealth is no guarantee against internal unrest, despite what leaders may believe".

A publication from the Africa Centre for Strategic Studies linking Africa and the Arab Spring appeared in November 2011. The contributors where writing from the platform of the United States(US) Department of Defense and essentially on behalf of US policy makers. Yet there contributions were incisive. In their summation, they contend that the events of the Arab Spring would serve as a 'trigger, rather than a driver' in other African countries. Specifically with respect to Sub-Saharan African countries of Guinea, Cote d'Ivoire, Niger, Nigeria and Zambia, the democratic surge, if that is what we would call the Arab Spring, was going on simultaneously in the Sub-Sahara as well as North Africa and the Middle East. It was the consensus of the working group that the access to information technology, the burgeoning population of the continent the capacity for collective action and public push for accountability has been enhanced. In the calculus, the citizens of the continent expect their leaders to act in a more democratic and accountable manner. In all, however, Sub-Saharan and by inference Africa's democratization experience predates the Arab Spring (Africa Center for Strategic Studies, 2011).

Malik and Awadallah (2011) examine effects of the Arab Spring on economics. They contend that the root of the region's economic failure lay in a 'statist model of development'. Furthermore, they postulate that an independent private sector is lacking, where revenues come only from oil sale remittances and dubious foreign aid and its various forms of intervention and redistribution is largely inefficient. In all these, the Arab world lacks a regional economic community, there have been in the past few decades an unprecedented youth bulge dramatically changing the demographic profile, and, finally, the typical Arab country can be characterized as a security state where its 'coercive apparatus is both fierce and extensive' (Malik \& Awadallah, 2011).

With the first year anniversary of the Arab Spring, Bauer and Schiller (2012), notes its continuation with differing character and impact. "In addition to the political and socio economic challenges for the transforming countries, it presents a wider geopolitical implication for the Middle East." (Bauer \& Schiller, 2012). He goes further to conclude, among others, that:

There will be no economic revolution dividend in 2012. Even worse, a further deterioration of the economic and social situation due to political instability could have a terribly negative impact on the medium and long-term perspectives of real change.

Revisiting the transitions in the Arab Spring, Sorenson (2012), contend that the belief in a genuine Arab Spring 
where the institution of democracy will be relatively quick and painless has all but vanished. This is so because 'absolute Arab rulers learned from the experiences of their former colleagues and tightened their rule, banding together in some cases and raising substantially the price of opposition'. Nevertheless, Sorenson concludes that the forces of the Arab Spring will be difficult to curb completely. If anything, 'Arab hopes for political transformation will continue, and democracy may spread slowly' (Soernson, 2012).

Two years into the Arab Spring, in 2013, de Luca (2013), is calling France to reposition its external policy in the Persian Gulf. This, de Luca considers imperative because of the strategic location of the Persian Gulf which can boast of 65 percent of the world's oil reserve and 40 percent of its gas. The stakes are even higher when it is considered that 'since 1980 the Persian Gulf represents the recipients of more than half of its arms exports (de Luca, 2013).

Finally, Mikail (2013), observes that the Arab Spring has gradually manifesting Islamist parties in its political sphere. To him, there is a subtle struggle between theocracy and democracy. Although, tension between secular and Islamists actors exist, secularist and liberals doubt the Islamists democratic commitment, the role of Islamist forces remain uncertain but their influence is clear in the Arab Spring transition process (Mikail, 2013).

All in all, the reviews have helped in grasping an understanding of the issues and praxis of the so called Arab Spring. It has located the Arab Spring in its local and global context. But the existing literature is lacking as to the Arab Spring's implication, if any, to the countries of the Sub-Saharan region especially Nigeria.

\section{Nigerian National Security since the Arab Spring}

It would not be appropriate to engage in a discourse on Nigerian national security without a background study. From political independence in 1960, national security has been the ostensible goal for every administration. Indeed, the conceptualization and practice of national security at least for the first three decades since independence have always emphasized physical security. Or, conversely put, national security meant physical security as it pertain the security or protection of the regime. Scant attention was given to the security of the citizen. The reason for this anomaly is not far-fetched. Approximately three years after independence, Nigeria became engulfed in all manner of political crises and conflicts that degenerated into a civil war by 1967 and ended in 1970 (Kirk-Green, 1971). Thereafter, with very brief years of civilian rule, the country was engaged in an orgy of coup d'etats and military administration which meant that civilian security took a backstage to regime security, although regime security to some extent implied the defense of Nigerian territorial integrity.

However, in the decade of the 1990s, with the cessation of cold war hostilities, the growth in capacity of civil society, the phenomenal growth in information technology, globalization in world affairs and the increase in the activities of the United Nations and its associated bodies such as the United Nations Development Programme (UNDP), the discourse on national security broadened in spectrum from the traditional physical security emphasis to a much more eclectic non-traditional category, human security. Economic, food, health, the environment, personal, community and political security became major ingredients in national security discourse (Osakwe, 2013).

The 1990s gave character to national security issues because is saw to the run up of the new millennium and the birth of Nigeria's Fourth Republic. The birth of the Fourth Republic meant that the deplorable era of the military had run its course. While the millennium development goals called for the eradication of poverty and hunger; universal primary education; promoting gender equality and empowering women; reducing child mortality; improving maternal health; combating HIV/AIDS, malaria and other diseases; ensuring environmental sustainability; and, developing a global partnership for development (Osakwe, 2013).

From the year 2000 to the present, the discourse on national security is still rife because the millennium development goals remain a mirage, and the various administrations appear to be in an eternal struggle to address the UNDP eclectic approach to national security which emphasizes human security. It is important to note that these national security or human security challenges are not of exotic origin. They are inalienable rights which have been captured by the 1999 Constitution of the Federal Republic of Nigeria and ensconced in chapters two, three and four.

All in all, the lack of a clear headway in Nigeria's national security or human security endeavor has resulted in all manner of conflicts including insurgencies. Some scholars have even created a kaleidoscope of conflicts using the six geo-political zones to delineate them (Albert, 2012). Furthermore, the tense national security atmosphere in Nigeria has brought about an inordinate budgetary increase on physical security to the detriment of education, health, agriculture to mention but a few. 


\section{Ripples from the Arab Spring and Its Implication to Nigerian National Security}

Mention has been made earlier about the lack of coherence in the events of Arab Spring. It has also been noted that generalizations would not be proper with respect to the Arab Spring because they are events that cut across cultural peculiarities, a complex interplay of religion and economic realities as well as the geo strategic environment. It is also a phenomenon that is not new to the region neither does it have a dialectical link to Nigeria or other Sub-Saharan countries. It has also been noted earlier that with respect to the democratic putsch of the Arab Spring, the countries in Sub-Saharan Africa have had an earlier experience. Regardless, when the upheavals of the Arab Spring began in 2011 similar upheavals were going on in some countries of the Sub-Saharan region including Nigeria. Furthermore, the Arab Spring is an on-going process. It is constantly evolving as it is revolutionary in its dismantling of certain political structures. Nevertheless, there are some ripples worthy of note and which may have some implications for Nigeria's National Security, notwithstanding what may have been highlighted in the review of related literature.

Prominent among the ripples is the fact that uprisings, demonstrations, upheavals, riotous reforms and even revolutions are difficult if not impossible to predict. Elsewhere, for instance, the French Revolution overthrew a King but it led to the crowning of an Emperor. In Egypt, Tunisia and Libya have seen the overthrow of authoritarian regimes but authoritarianism still exist in those countries. In the case of Egypt, it can be conjectured that the military used social demonstrators to execute a coup d'etat that have found them back in power. Its implication in Nigeria is that efforts should be made to properly manage demonstrations or social outbursts so as not to have a deleterious national security environment.Conversely, Nigeria's national security managers, policy makers and implementers, must work on how to contain and control certain information and communication infrastructure which were the frameworks that the demonstrators in the Arab Spring used and still use to a great effect. It has been reasoned that if there was anything revolutionary about the Arab Spring it was the revolution in the use of the social media and information technology. If this digital technology were used effectively in a crises and conflict situation in Nigeria it would be almost insurmountable to control.

Riots, demonstrations and uprisings have a way of triggering primordial ethnic and cultural sentiments that could lead to prolonged conflict or even civil war. The yearnings in Syria and Libya have produced civil war and situation likely to degenerate into a civil war respectively. In Nigeria such clamor for good governance, if mismanaged, can lead to a civil war not minding Nigeria's earlier experience with a civil war.

A plausible implication of the Arab Spring, is the dismantling of armed groups that employ terror tactics in their operations. Terror mercenaries displaced from Yemen, Bahrain and Libya or even those not attracting "good funds" from countries associated with state terrorism, such as Libya, Iran and Syria would utilize the poorly manned Nigeria's border with the Sahel to infiltrate into Nigeria and enhance the capacity of disaffected group or groups. It would have and perhaps it is already having grave implications for Nigeria's national security when we consider that part of the altered security situation in northeast Nigeria has been associated with non-Nigerians. Closely tied to this is that the financing of these disaffected groups could be easily managed outside the immediate borders of Nigeria even with any mitigating ECOWAS protocol.

The Sahel aside, many countries of the Arab Spring share with Nigeria, littoral credentials. As a result, the waterways could be an effective line of communication especially with the movement of munition and ammunition of war. It is evident that the Nigerian Navy or indeed, the Nigerian Defense Forces does not have full control of her maritime borders. Even more deplorable is the recent exposure that corruption, Nigeria's bane, has found a comfortable home amongst the personnel of the Joint Task Force in the Niger Delta (This Day, 2013).

The one combustible element in the Arab Spring is the utilization of the youth, largely educated and unemployed. In Nigeria, likewise, the data is sobering. With an approximate population of about 170 million, of which about 67 million are unemployed; 80 percent of the unemployed are uneducated and tertiary institutions turning out about 4.5 million graduates without a job, a copy of the Arab Spring processes will have serious implications for Nigeria's national security (Osakwe, 2013). The potency of the youth population bulge in the Arab Spring underscores the grave implications for Nigeria's national security.

Religious threat to national security is a ripple out of the Arab Spring. In the countries of the Arab Spring, the major plays are between the Sunni and Shia religious sects. The intra-religious conflict between these sects is predominantly mid-wifed by two godfathers, Saudi Arabia to the Sunni's and Iran for the Shia sect. Religious threat to national security in Nigeria is plausible. In fact, Jumare and Mukhtar (2013), using Sokoto and Zamfara States, contend that ethno-religious conflicts essentially derive from intra-religious conflicts as opposed to inter-religious conflicts. Although it is still of importance to Nigerian national security but it would be of a 
sectional, albeit of a regional dimension. It will not play out in Nigeria as a Sunni or Shia conflict but will be rooted in the cultural practice of religion.

The countries of the Arab Spring collectively hold the majority of crude oil and gas deposits of the world. In the initial months of the Arab Spring, it affected the stability of the oil and gas markets and their national incomes. Plus it attracted the attention of the international community. The influence of the international community would certainly infringe on sovereignty and territorial integrity. The implications for disruption in resources and revenue would not be averse to Nigeria and her national security managers.

\section{Conclusion}

When all is said, we have looked at the Arab Spring or Arab Awakening and its antecedents. We have tried to avoid models, frameworks and generalizations. We have used some of the literature of the phenomenon to capture the significant underpinnings, the causes and course of the Arab Spring. We have also appraised Nigeria's national security environment from a historical perspective while noting similarity of events with the Arab Spring. The peculiarity of the Arab spring does not translate to a direct replication in Nigeria. The peculiar factors of Nigerian politics, religion, ethnic composition, resource base, external image, global reputation, leadership qualities and/or force structure makes it difficult to make a 'copy and paste' conclusion for Nigeria. It is clear that there is no clear link or obvious implication of the Arab Spring to Nigeria's national security. Like the countries of the Arab Spring, Nigeria must assess and manage her national security issues based on its peculiarities. What is certain and inalienable is that good governance is a panacea to disharmony and that effect of repression and bad governance lead to discord and disharmony in society but it explodes and presents itself from its own cultural milieu. What is immanent in the Arab Spring have always been extant in Nigeria. Forcing a link or an implication with respect to Nigeria's national security is a normative academic exercise.

\section{References}

Africa Center for Strategic Studies. (2011). Africa and the Arab spring: A new era of democratic expectations (Special Report No. 1). Washington D.C.

Albert, I. O., Eselebor, W., \& Danjibo, N. (Eds.). (2012). Peace, security and development in Nigeria. Abuja: Society for Peace Studies and Practice.

Alfano, A. (2011). A personal perspective on the tunisian revolution. In A. Mckay (Ed.), The Arab spring of discontent. A Collection of E-International Relations.

Anderson, L. (2011, May/June). Demystifying the Arab spring. Foreign Affairs, 90(3), 2-7.

Bauer, M., \& Schiller, T. (2012). The Arab spring in 2012. C.A. Perspectives, (1). Munich: Center for Applied Policy Research.

Byman, D. (2011, May/June). Terrorism after the revolutions. Foreign Affairs, 90(3), 48-57.

de Luca, A. (2013). Defense diplomacy and the Arab spring: New ventures and the French presence in the persian gulf. Air and Space Power Journal, 4(2), 13-24.

Docherty, L. (2011). Introduction. In Conservative Middle East Council. The Arab Spring: Implications for British Policy. London.

Doran, M. S. (2011, May/June). The Heirs of Nasser. Foreign Affairs, 90(3), 17-25.

Entessar, N. (2011). The Arab uprisings: Opportunities and challenges for Iran. In A. Mckay (Ed.), The Arab Spring of Discontent. A Collection of E-International Relations.

Goldstone, J. (2011, May/June). Understanding the revolutions of 2011. Foreign Affairs, 90(3), 8-16.

Hamid, S. (2011, May/June). The rise of the islamists. Foreign Affairs, 90(3), 40-47.

Jones, C. (2011). Yemen and the Arab spring: Moving beyond the tribal order? In A. Mckay (Ed.), The Arab Spring of Discontent. A Collection of E-International Relations.

Jones, T. (2011). The persian gulf tinderbox. In A. Mckay (Ed.), The Arab Spring of Discontent. A Collection of E-International Relations.

Jumare, I., \& Mukhtar, T. (2013). Ethno-religious conflicts and transitional democracy: A study of Sokoto and Zamfara states. In O. Tangban, \& C. Osakwe (Eds.), Perspectives in African Historical Studies: Essays in Honour of Professor Chinedu Nwafor Ubah (pp. 407-418). Kaduna: Nigerian Defence Academy Press.

Kirk-Greene, A. H. M. (1971). Crisis and conflict in Nigeria: A documentary source book, 1966-1970 (Vol. I). 
London: Oxford University Press.

Malik, A., \& Awadallah, B. (2011). The economics of the Arab spring. Working Paper WPS/2011-23. London: Centre for the Study of African Economies.

McKay, A. (2011). Introductory notes. In A. McKay (Ed.), The Arab spring of discontent. A Collection of E-International Relations.

Mikail, B. (2013). Religion and politics in Arab transitions. Air and Space Power Journal, 4(3), 89-96.

O'Connell, M. E. (2011). How to save a revolution. In A. Mckay (Ed.), The Arab Spring of Discontent. A Collection of E-International Relations.

Osakwe, C. (2013, July). National security and the transformation agenda in Nigeria: Issues and challenges. Badala Journal of Arts and Social Sciences, 9(9).

Osakwe, C. (2013, November). Youth, unemployment and national security in Nigeria. Paper delivered at the Nigerian Army School of Infantry (NASI).

Rogan, E. (2011). Regional overview. In Conservative Middle East Council. The Arab Spring: Implications for British Policy. London.

Shaikh, S. (2011). Gulf states: The challenge of reform. In Conservative Middle East Council. The Arab Spring: Implications for British Policy. London.

Shehata, D. (2011, May/June). The Fall of the Pharaoh. Foreign Affairs, 90(3), 26-32.

Sorenson, D. S. (2012). Revisiting transitions in the Arab world, spring or fall? Air and Space Power Journal, $3(1), 5-34$.

Taleb, N. N., \& Blyth, M. (2011, May/June). The black swan of Cairo. Foreign Affairs, 90(3), 33-39.

This Day Newspaper. (2013, November 22).

Willis, M. J. (2011). Tunisia: The trailblazer and the benchmark. In Conservative Middle East Council. The Arab Spring: Implications for British Policy. London.

\section{Copyrights}

Copyright for this article is retained by the author(s), with first publication rights granted to the journal.

This is an open-access article distributed under the terms and conditions of the Creative Commons Attribution license (http://creativecommons.org/licenses/by/3.0/). 